\title{
Effects of Neutralized Schwertmannite from the Disused Yanahara Mine as a New Agricultural Material for Reducing the Transfer of Radiocesium from Soil to Crops
}

\author{
Teruhiko ISHIKAWA ${ }^{1 *}$, Taro HARADA ${ }^{1}$, Fumio AKAHORI ${ }^{2}$ and \\ Yasumasa SAKURAI ${ }^{3}$ \\ ${ }^{1}$ Department of Science Education, Graduate School of Education, Okayama University (Okayama, \\ Okayama 700-8530, Japan) \\ ${ }^{2}$ Unekura Mining Co., Ltd (Kume, Okayama 708-1527, Japan) \\ ${ }^{3}$ Dowa Technology Co., Ltd (Honjo, Saitama 367-0002, Japan)
}

\begin{abstract}
Following the accident at the Fukushima Daiichi Nuclear Power Plant, agricultural fields in Fukushima Prefecture were subject to severe radioactive contamination. Given the fact that radiocesium is readily transferred along the food chain and potentially poses a radiation risk to humans, effective methods of lowering the transfer of radioactivity from soil to crops are needed. We examined the effect of neutralized schwertmannite (NS) produced in the disused Yanahara mine as a new agricultural material for reducing radiocesium uptake by crops. The application of NS to soil at $1 \%$ or $5 \%$ showed inhibitory effects on radiocesium accumulation in the harvests of four upland crops (sweet potato, radish, turnip, and Chinese cabbage) and rice. Substantial amounts of radiocesium were detected in brown rice and hulls following cultivation in soil with recommended levels of exchangeable potassium $\left(>200 \mathrm{mg} \mathrm{kg}^{-1}\right)$. Decreased levels of radiocesium were observed in both tissues following the application of 5\% NS, suggesting additional effects of NS application in potassium-rich soil. Our results indicated the efficacy of NS application and suggest its practical use in minimizing the radioactivity in crops cultivated in radiocesium-contaminated soil.
\end{abstract}

Discipline: Agricultural environment

Additional key words: radioactivity, transfer factor, iron oxyhydroxysulfate

\section{Introduction}

Radiocesium (i.e., radioactive isotopes ${ }^{134} \mathrm{Cs}$ and ${ }^{137} \mathrm{Cs}$, with half-lives of 2 and 30 years, respectively) has been introduced into the environment by the testing of nuclear weapons and by accidents at nuclear power plants. In March 2011, large amounts of radionuclides were widely released in eastern Japan by the accident at the Fukushima Daiichi Nuclear Power Plant (FNPP) (Fig. 1). Because both isotopes of radiocesium have relatively long half-lives and high biological availability (Zhu \& Smolders 2000), concentrations of radiocesium in agricultural fields have been monitored by some organizations (Nuclear Regulation Authority and Fukushima Prefecture). The severe radioactive contamination of aquatic resources and soil in eastern Japan is damaging to agriculture, particularly in Fukushima Prefecture. Radiocesium is readily transferred along the food chain and may pose a long-term radiation risk to humans.
Potassium (K), which is chemically similar to cesium (Cs), influences Cs dynamics in soil, and radiocesium uptake by plants is strongly dependent on $\mathrm{K}$ concentration (Zhu 2001). As an agricultural countermeasure to reduce radiocesium uptake by rice or upland crops, $\mathrm{K}$ fertilization is an effective and practical method for several soil types. The recommended level of exchangeable $\mathrm{K}$ in soil for reducing the radiocesium content of rice below the regulation value $\left(100 \mathrm{~Bq} \mathrm{~kg}^{-1}\right)$ is approximately $200 \mathrm{mg} \mathrm{kg}^{-1}$ (Kato et al. 2015). In Fukushima Prefecture, more than $250 \mathrm{mg} \mathrm{kg}^{-1}$ soil containing exchangeable $\mathrm{K}_{2} \mathrm{O}$ is recommended in rice cultivation. However, further increases in exchangeable $\mathrm{K}$ level only result in slight changes in its inhibitory effect on radiocesium uptake. In addition to $\mathrm{K}$ fertilization, effective methods of lowering the transfer of radiocesium from soil to crops are urgently needed. We have been searching for an amendment to reduce the transfer of radioactivity to crops.

In the disused Yanahara mine, located in Misaki town, 


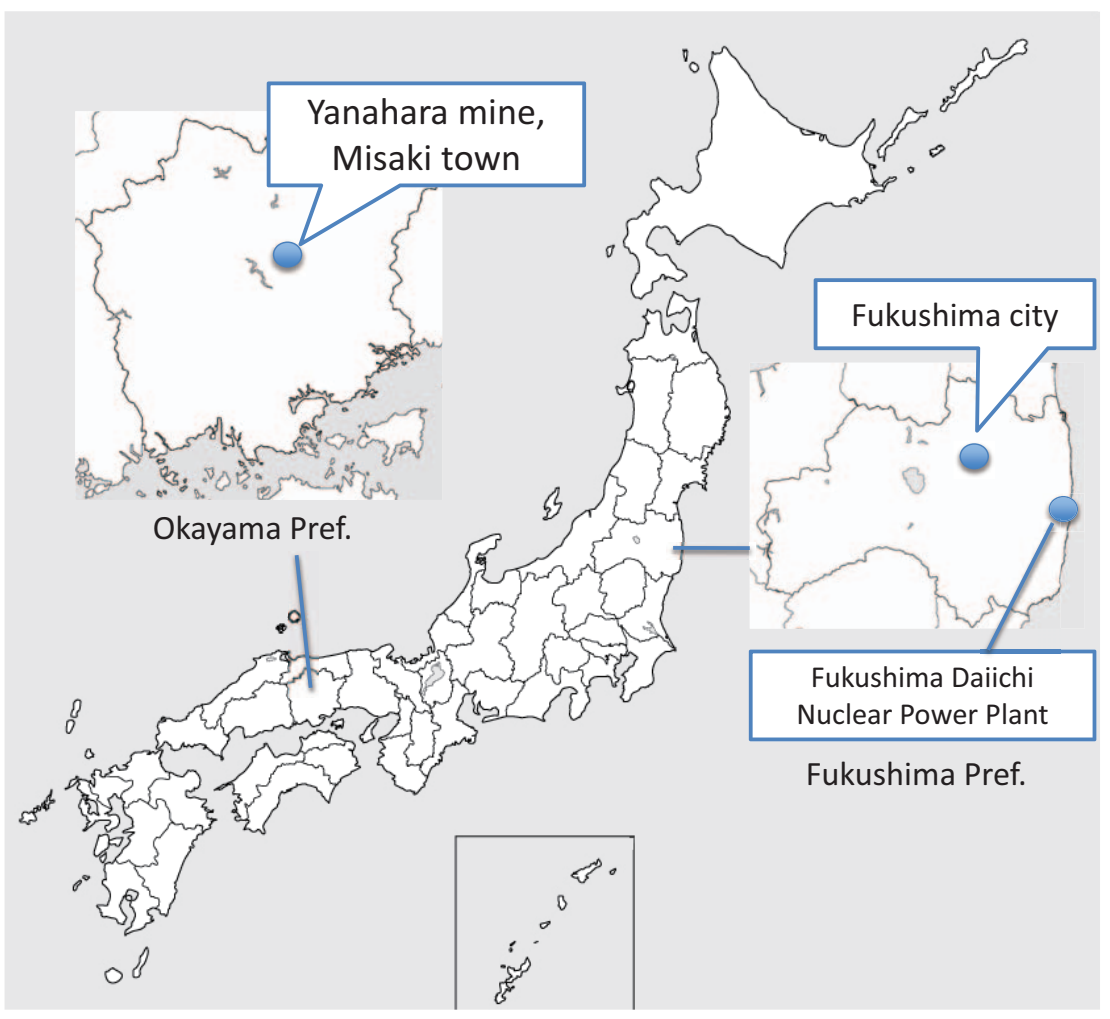

Fig. 1. Locations of Fukushima Daiichi nuclear power plant and Fukushima city in Fukushima Prefecture, and Yanahara mine in Misaki town, Okayama Prefecture

Okayama Prefecture (Fig. 1), a large amount of acid rock drainage (ARD) containing Fe (II) sulfate and other minerals is being continuously released, and ARD treatment (including oxidative iron salt precipitation and its neutralization with lime) is performed for environmental conservation. In this process, a large quantity (approx. 3,000 tons a year) of precipitate is produced as a byproduct containing neutralized schwertmannite (NS) as a main component. Schwertmannite (Bigham et al. 1994) is an iron oxyhydroxysulfate mineral with an ideal chemical formula of $\mathrm{Fe}_{8} \mathrm{O}_{8}(\mathrm{OH})_{6}\left(\mathrm{SO}_{4}\right) \cdot \mathrm{nH}_{2} \mathrm{O}$. Schwertmannite adsorbs various metal ions (Kawano et al. 2006), and this chemical property makes it a possible radiocesium adsorbent. Because NS from the disused Yanahara mine contains only trace amounts of harmful heavy metals (Table 1) that are below regulation values (Ministry of the Environment), it can be used as an agricultural material with the approval of Japan's Ministry of Agriculture, Forestry and Fisheries.

The present study was undertaken to confirm the potential of NS as a material for lowering the transfer of radiocesium from soil to crops. As a first step toward achieving this goal, several common upland crops and rice, a main agricultural crop in Fukushima Prefecture, were cultivated on farmlands in Fukushima and the radiocesium levels in the harvests were evaluated.
Table 1. Chemical composition of neutralized schwertmannite (NS)

\begin{tabular}{cccc}
\hline \hline Component & $\begin{array}{c}\text { Composition } \\
(\mathrm{wt} \%)\end{array}$ & Component & $\begin{array}{c}\text { Composition } \\
\text { (wt\%) }\end{array}$ \\
\hline $\mathrm{Ca}$ & 8.83 & $\mathrm{Zn}$ & 1.20 \\
$\mathrm{SO}_{4}$ & 10.20 & $\mathrm{Mn}$ & 0.32 \\
$\mathrm{Fe}$ & 27.40 & $\mathrm{Cu}$ & 0.33 \\
$\mathrm{Na}$ & 0.045 & $\mathrm{Cd}$ & $<0.01$ \\
$\mathrm{~K}$ & $<0.01$ & $\mathrm{~Pb}$ & $<0.01$ \\
$\mathrm{Al}$ & 5.05 & $\mathrm{Cr}$ & $<0.01$ \\
$\mathrm{Si}$ & 1.49 & $\mathrm{As}$ & $<0.01$ \\
$\mathrm{Sr}$ & 0.22 & $\mathrm{OH}, \mathrm{H}_{2} \mathrm{O}$ & 44.80 \\
$\mathrm{Ba}$ & 0.082 & \multicolumn{3}{c}{} \\
\hline
\end{tabular}

\section{Materials and methods}

\section{Preparation and chemical analysis of neutralized schwertmannite (NS)}

NS obtained from the disused Yanahara mine was used after adjusting to $15 \mathrm{wt} \%$ of water and sieving to achieve a particle size of approximately $2 \mathrm{~mm}$. The chemical composition of NS was determined by dissolving in $70 \%$ nitric acid followed by ICP-AES analysis using a SPS3500DD ICP analyzer (Seiko Instruments Inc., Chiba, Japan). 
Table 2. Chemical properties of the soil used in the present study

\begin{tabular}{ccc}
\hline \hline \multirow{2}{*}{ Parameter } & \multicolumn{2}{c}{ Values } \\
\cline { 2 - 3 } & Field 1 & Field 2 \\
\hline $\mathrm{pH}\left(\mathrm{H}_{2} \mathrm{O}\right)$ & 5.71 & 5.61 \\
$\mathrm{EC}(1: 5)\left(\mathrm{mS} \mathrm{cm}^{-1}\right)$ & 0.319 & 0.082 \\
Exchangeable $\mathrm{K}\left(\mathrm{mg} \mathrm{kg}^{-1}\right)$ & 840 & 440 \\
Exchangeable $\mathrm{Ca}\left(\mathrm{mg} \mathrm{kg}^{-1}\right)$ & 4796 & 3075 \\
Exchangeable $\mathrm{Mg}\left(\mathrm{mg} \mathrm{kg}^{-1}\right)$ & 771 & 376 \\
Total nitrogen $\left(\mathrm{mg} \mathrm{kg}^{-1}\right)$ & 9.9 & 7.4 \\
\hline
\end{tabular}

Data are the means of two values obtained by the measurement of soil samples from separate spots.

\section{General planting methods}

\section{(1) Experiment 1}

Sweet potato (Ipomoea batatas L. 'Beniazuma'), radish (Raphanus sativus L. 'Comet'), turnip (Brassica rapa L. 'Natsukomachi'), and Chinese cabbage (B. rapa L. 'Matsushima') were cultivated in a field (Field 1) located in Fukushima city, Fukushima Prefecture, Japan. Three ridges were built for each crop, representing three experimental sections: non-treatment, $1 \% \mathrm{NS}$, and $5 \% \mathrm{NS}$. In the ridges for $1 \% \mathrm{NS}$ and $5 \% \mathrm{NS}, 1.6$ and $8.0 \mathrm{~kg}$ of NS, respectively, were mixed into $0.15 \mathrm{~m}^{-3}$ of soil, with NS distributed in the top 15-cm layer. Table 2 lists the chemical properties of the soil in Field 1 before NS application. On the day following planting or sawing, $40 \mathrm{~g} \mathrm{~m}^{-2}$ of ammonium phosphate was added as fertilizer to the soil. Three seedlings of sweet potato were planted on $3.0 \mathrm{~m}^{2}$ of the ridge for each experimental section on May 20, 2014, and the tuberous roots were harvested on October 15, 2014. Seeds of red radish and turnip were sown on August 30, 2014, and the underground parts of radish and turnip were harvested on September 29 and October 27, 2014, respectively. The areas of radish and turnip cultivation for each experimental section were 1.2 and $0.6 \mathrm{~m}^{2}$, respectively. For Chinese cabbage, seeds were sown on $0.6 \mathrm{~m}^{2}$ of the ridge for each experimental section on August 26, 2014, and the aboveground parts were harvested on November 17, 2014.

(2) Experiment 2

Rice (Oryza sativa L. 'Koshihikari') was cultivated in the paddy field (Field 2) in the same region as that of experiment 1. Two separate plots of rice paddy were prepared, representing two experimental sections, the control, and 5\% NS. Table 2 lists the chemical properties of the soil in Field 2 before NS application. On the day after planting, $40 \mathrm{~g} \mathrm{~m}^{-2}$ of ammonium phosphate was added as fertilizer to the soil. The dates of planting and harvesting were May 30 and October 16, 2014, respectively.

\section{Sample preparation and radioactivity measurement} (1) Experiment 1

The surface of the harvested part of each crop was washed sufficiently to remove soil particles. The harvests from each experimental section weighing $1 \mathrm{~kg}$ or more for each were combined and transported for radioactivity measurement immediately after moderate air drying. The radioactivity of ${ }^{134} \mathrm{Cs}$ and ${ }^{137} \mathrm{Cs}$ from the samples was measured with an EMF211 NaI (Tl) scintillation gamma-ray spectrometer (EMF Japan Co., Ltd., Osaka, Japan), with 1 Bq $\mathrm{kg}^{-1}$ as the lower detection limit. Soil samples were collected approximately $10 \mathrm{~cm}$ below the soil surface before the mixing of NS and the measurement of radioactivity in those samples. This method was adopted because NS and the majority of roots were distributed in the top 15-cm layer of soil. The soil concentrations of exchangeable potassium and other components were determined by the extraction of air-dried soil followed by SPS-5100 ICP-AES measurement (SII Nanotechnology Co., Ltd., Tokyo, Japan) of the extract. (2) Experiment 2

Harvested rice plants were dried on rice-drying racks outside for 11 days, followed by threshing and hulling. Parts of the isolated brown rice grains and hulls from each experimental section weighing $500 \mathrm{~g}$ or more each were combined. ${ }^{134} \mathrm{Cs}$ and ${ }^{137} \mathrm{Cs}$ radioactivity from the samples was measured with a CANBERRA GC2020 Ge gamma-ray spectrometer (Canberra Industries, Inc., Meriden, CT, USA), with $1 \mathrm{~Bq} \mathrm{~kg}^{-1}$ as the lower detection limit. The radioactivity of soil samples collected within $10 \mathrm{~cm}$ below the soil surface was also measured before the mixing of NS. The concentrations of exchangeable potassium in the soil were determined as in experiment 1 .

\section{Evaluation of the adsorption ability of NS for cesium ions}

An aqueous solution of cesium chloride $\left(1.0 \times 10^{-3}\right.$ mol L ${ }^{-1}, 10 \mathrm{~mL}$ ) was mixed with $1.0 \mathrm{~g}$ of NS. The concentration of cesium ions in the supernatant of the mixture was monitored using a Shimadzu AA-6300 atomic absorption spectrometer (Shimadzu Co., Ltd., Kyoto, Japan).

\section{Results}

\section{Effect of neutralized schwertmannite (NS) application on the concentration and transfer factor of radiocesium in upland crops}

The soil in Field 1 was an Andosol, and the total radiocesium $\left({ }^{134} \mathrm{Cs}\right.$ and $\left.{ }^{137} \mathrm{Cs}\right)$ concentration in the soil was 2978 \pm 118 [mean \pm standard error $(\mathrm{SE}), \mathrm{n}=21$ ] Bq kg dry weight $(\mathrm{DW})^{-1}$. The soil contained $84 \mathrm{mg}$ of exchangeable potassium per $100 \mathrm{~g}$ DW on average. In total, about 4.5-6 $\mathrm{kg}$ of sweet potato, 1-1.2 kg of radish, 1-1.2 kg of turnip, and $2 \mathrm{~kg}$ of Chinese cabbage were harvested in each experi- 
mental section. NS application showed no visible undesirable effect on crop growth and yield. As shown in Fig. 2, low levels of ${ }^{134} \mathrm{Cs}$ were detected in sweet potato and turnip without NS application at cultivation. The level was lowered by the application of $1 \%$ or $5 \% \mathrm{NS}$, although the difference was insignificant. In all four crops investigated, substantial levels of ${ }^{137} \mathrm{Cs}$ were detected in non-treatment, but radioactivity levels were lowered by NS application. It was observed that $5 \%$ NS lowered the level significantly in sweet potato, turnip, and Chinese cabbage, and no radiocesium was detected in radish and turnip cultivated in soil containing 5\% NS. The transfer of total radiocesium from the soil to the harvest, evaluated by the transfer factor, tended to be reduced by NS application (Table 3). The effect was significant in turnip when 5\% NS was applied.

\section{Effect of NS application on the concentration and transfer factor of radiocesium in rice}

The total $\left({ }^{134} \mathrm{Cs}\right.$ and $\left.{ }^{137} \mathrm{Cs}\right)$ radiocesium concentration in the Andosol soil for rice cultivation (Field 2) was $3848 \pm$ 147 (mean $\pm \mathrm{SE}, \mathrm{n}=10$ ) $\mathrm{Bq} \mathrm{kg} \mathrm{DW}{ }^{-1}$. The soil for these two conditions contained $44 \mathrm{mg}$ of exchangeable potassium per $100 \mathrm{~g}$ DW on average. The yield of grain was approximately $500 \mathrm{~g} \mathrm{~m}^{-2}$ and neither growth nor grain production appeared to differ between both conditions. For both ${ }^{134} \mathrm{Cs}$ and ${ }^{137} \mathrm{Cs}$, the radioactivity level in brown rice was lower than that in the hull. The application of $5 \%$ NS tended to reduce the level similarly in both components, although the effect was insignificant due to of the lack of repetitive measurement (Fig. 3). The decrease in the transfer factor of total radiocesium was approximately $50 \%$ in both components (Table 4).

\section{Adsorption ability of NS for cesium ions}

The cesium ion concentration in aqueous media gradually decreased with the addition of NS to the solution (Fig. 4). Similar results were obtained from a couple of experiments where ion removal reached $61 \%$ after 10 days. The adsorption ability of NS for cesium ions was confirmed, although the exact mechanism awaits further studies.

\section{Discussion}

A substantial amount of radiocesium was detected in the farmland soil used in the present study, although the level was lower than that in the area near the FNPP (Yamashita et al. 2014). The differences in the concentration and transfer factor of radiocesium among the crops may have been caused by differences in the cesium uptake ability among plant species (Buysse et al. 1996, Gouthu et al. 1997) or in the partitioning of cesium in planta (Buysse et al. 1995, Tsukada et al. 2002). However, the application of neutralized schwertmannite (NS) to the soil at $1 \%$ or $5 \%$ as
(A)

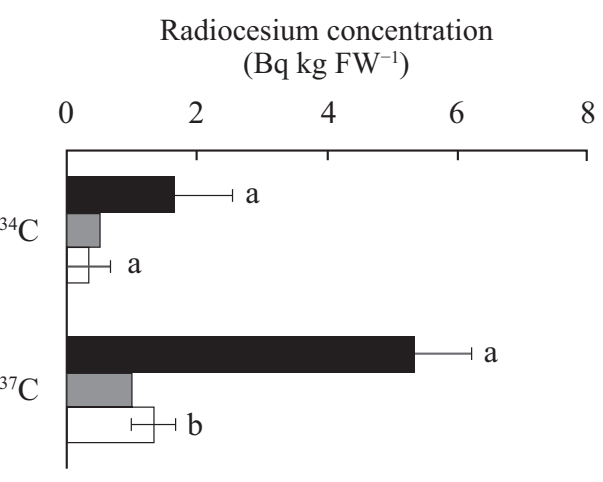

(B)

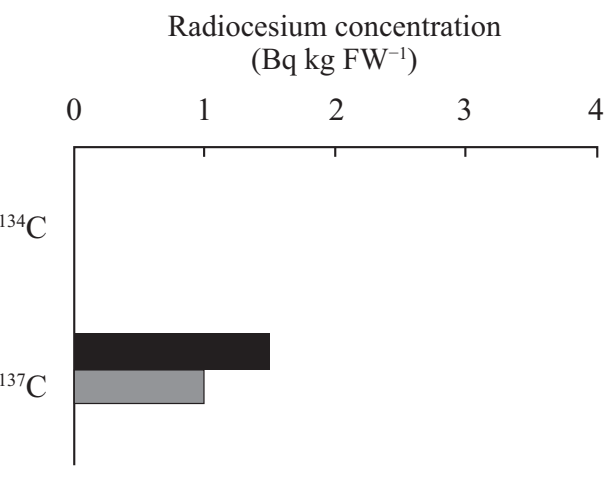

(C)

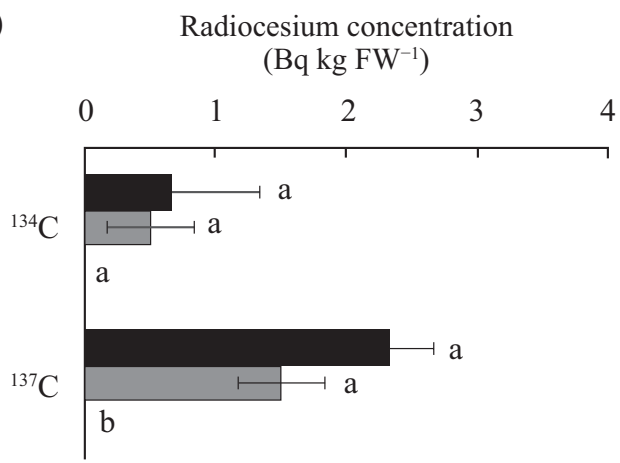

(D)

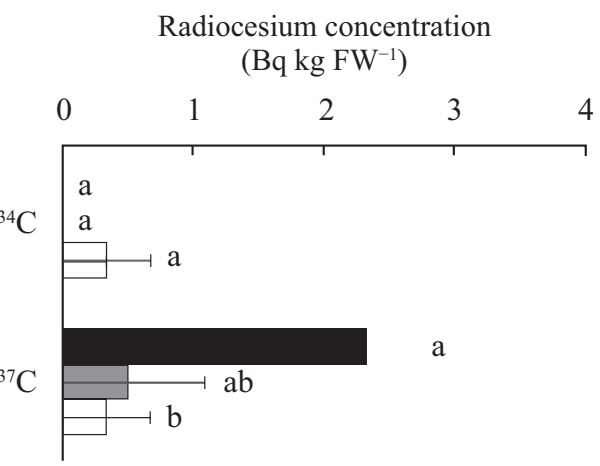

Fig. 2. Effects of neutralized schwertmannite (NS) application on radiocesium concentrations in upland crops The radioactivities of ${ }^{134} \mathrm{Cs}$ and ${ }^{137} \mathrm{Cs}$ in non-treatment (black bars), 1\% NS (gray bars), and 5\% NS (white bars) were measured in sweet potato (A), radish (B), turnip (C), and Chinese cabbage (D). Data are means \pm $\mathrm{SE}(\mathrm{n}=3)$ and the same letters among treatments show that a significant difference $(P<0.05)$ was not detected by Tukey's test. The absence of a letter denotes insufficient data for the test. 
Table 3. Effects of neutralized schwertmannite (NS) application on the transfer factor of total radiocesium in upland crops

\begin{tabular}{cccc}
\hline \hline \multirow{2}{*}{ Plant species } & \multicolumn{3}{c}{ Treatment } \\
\cline { 2 - 4 } & Non-treatment & $1 \% \mathrm{NS}$ & $5 \% \mathrm{NS}$ \\
\hline Sweet potato & $0.002 \pm 0.0005 \mathrm{a}$ & 0.0006 & $0.0007 \pm 0.0003 \mathrm{a}$ \\
Radish & 0.0005 & 0.0004 & 0 \\
Turnip & $0.0009 \pm 0.0003 \mathrm{a}$ & $0.0004 \pm 0.0002 \mathrm{ab}$ & $0 \pm 0 \mathrm{~b}$ \\
Chinese cabbage & $0.001 \pm 0.0001 \mathrm{a}$ & $0.0003 \pm 0.0002 \mathrm{a}$ & $0.0002 \pm 0.0002 \mathrm{a}$ \\
\hline
\end{tabular}

The transfer factor is defined as the total radiocesium concentration in the harvest $\left[\mathrm{Bq} \mathrm{kg}\right.$ fresh weight $\left.(\mathrm{FW})^{-1}\right]$ divided by that in the soil $\left[\mathrm{Bq} \mathrm{kg}\right.$ dry weight $\left.(\mathrm{DW})^{-1}\right]$. Data are means $\pm \mathrm{SE}(\mathrm{n}=3)$, with the exception of the means of two values shown without SE. The same letters among treatments show that a significant difference $(P<0.05)$ was not detected by Tukey's test.

Radiocesium concentration $\left.(\mathrm{Bq} \mathrm{kg})^{-1}\right)$

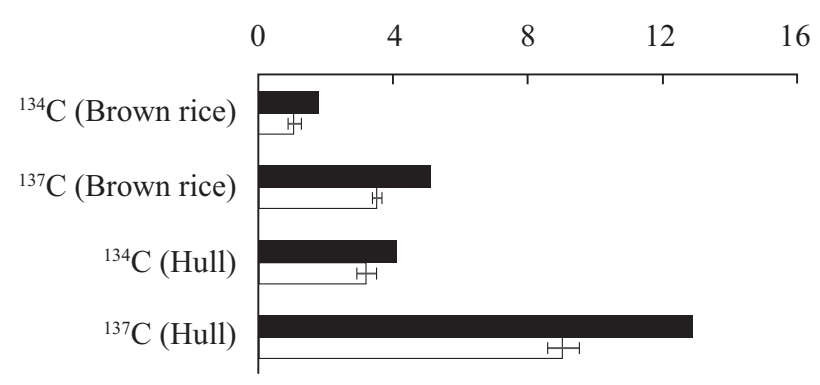

Fig. 3. Effects of neutralized schwertmannite (NS) application on radiocesium concentrations in rice The radioactivities of ${ }^{134} \mathrm{Cs}$ and ${ }^{137} \mathrm{Cs}$ in control (black bars) and 5\% NS (white bars) were measured in brown rice and hulls. Data are single measured values representing multiple rice plants (control) and mean \pm SE for brown rice $(\mathrm{n}=9)$ and hulls $(\mathrm{n}=3)$ for $5 \%$ NS.

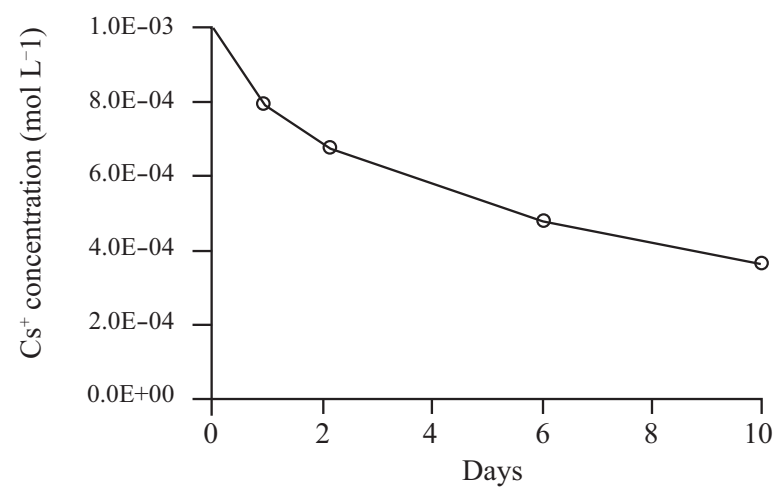

Fig. 4. Decrease of cesium ion concentration with the addition of neutralized schwertmannite (NS)

Data for cesium ion concentration are the means of two experiments.

a whole tended to show inhibitory effects on radiocesium accumulation in the harvests of all four upland crops and rice. Significant effects were mainly obtained when $5 \%$ NS was added to the soil, implying that a substantial amount of
Table 4. Effects of neutralized schwertmannite (NS) application on the transfer factor of total radiocesium in rice

\begin{tabular}{lcc}
\hline \hline \multirow{2}{*}{ Component } & \multicolumn{2}{c}{ Treatment } \\
\cline { 2 - 3 } & Control & $5 \%$ NS \\
\hline Brown rice & 0.0024 & $0.0012 \pm 0.000051$ \\
Hull & 0.0060 & $0.0031 \pm 0.00019$ \\
\hline
\end{tabular}

The transfer factor is defined as the total radiocesium concentration in the harvest $\left(\mathrm{Bq} \mathrm{kg}^{-1}\right)$ divided by that in the soil $\left[\mathrm{Bq} \mathrm{kg}\right.$ dry weight $\left.(\mathrm{DW})^{-1}\right]$. Data are single calculated values that represents multiple rice plants (control) and the means \pm SE for brown rice $(n=9)$ and hulls $(n=3)$ for $5 \%$ NS.

NS must be supplied for practical use. Furthermore, the in vitro absorption of cesium by NS was demonstrated qualitatively. These results agree with our expectations, based on a deduced chemical property of NS that it preferentially captures cesium in soil. However, another mechanism may need to be considered, given the assumption that such low concentrations of NS capture radiocesium in soil. It is worth investigating whether the supply of a mineral such as iron to soil affects the cationic environment in the rhizosphere. The involvement of bacteria might also be taken into consideration as some bacteria reportedly accumulate cesium in soil (Kuwahara et al. 2011) or affect radiocesium uptake by crops (Djedidi et al. 2015).

Fertilization with abundant potassium has an inhibitory effect on cesium uptake by roots (Shaw 1993), in which $\mathrm{K}^{+}$ transporter- or $\mathrm{K}^{+}$channel-mediated mechanisms are likely to be involved (Zhu \& Smolders 2000). Because the soil used in the present study contained sufficient exchangeable potassium without $\mathrm{KCl}$ application, our results indicated the efficacy of NS application to potassium-rich soil. Substantial amounts of radiocesium were detected in brown rice cultivated in soil with the recommended level of $\mathrm{KCl}$ fertilization, and even higher levels were detected in hulls. The decreased levels of radiocesium observed in both tis- 
sues following the application of 5\% NS suggest additional effects of NS application to potassium-rich soil. Even though the present study did not monitor changes in the concentration of exchangeable potassium, the involvement of potassium in reduced radiocesium accumulation in the crops as observed here could not be denied. However, the exchangeable potassium additionally supplied by NS appears to be negligible, judged by the low level of potassium content in NS $(<0.01 \mathrm{wt} \%$, Table 1$)$. This practice will prove practical when employed to minimize the radioactivity in crops cultivated in radiocesium-contaminated soil.

This is the first report to show the effects of NS, a byproduct of mining, on the transfer of radiocesium from soil to crops. The use of NS may alleviate the difficulties of using agricultural environments polluted by radiocesium contamination. Further studies are required for a more detailed evaluation of its efficacy, where it should be compared to that of other substances such as $\mathrm{KCl}$ and zeolite for practical use.

\section{Acknowledgements}

The authors wish to gratefully thank Honjo Bunseki Center Co., Ltd. for the radioactivity measurements, Seikaken Bunseki Center Co., Ltd. for the exchangeable potassium analysis, and the Division of Instrumental Analysis, Okayama University for the atomic absorption spectrum measurements.

\section{References}

Bigham, J. M. et al. (1994) Schwertmannite, a new iron oxyhydroxysulfate from Pyhasalmi, Finland, and other localities. Mineral Mag., 58, 641-664.

Buysse, J. et al. (1995) The distribution of radiocesium and potassium in spinach plants grown at different shoot temperatures. J. Plant Physiol., 146, 263-267.

Buysse, J. et al. (1996) Genotypic differences in the uptake and distribution of radiocaesium in plants. Plant and Soil, 178, 265-271.

Djedidi, S. et al. (2015) Evaluation of the possibility to use the plant-microbe interaction to stimulate radioactive ${ }^{137} \mathrm{C}$ accumulation by plants in a contaminated farm field in Fukushima, Japan. J. Plant Res., 128, 147-159.

Fukushima prefecture: Fukushima prefecture radioactivity measurement map. http://fukushima-radioactivity.jp

Gouthu, S. et al. (1997) Screening of plant species for comparative uptake abilities of radioactive $\mathrm{Co}, \mathrm{Rb}, \mathrm{Sr}$ and $\mathrm{Cs}$ from soil. J. Radioanal. Nucl. Chem., 222, 247-251.

Kato, N. et al. (2015) Potassium fertilizer and other materials as countermeasures to reduce radiocesium levels in rice: Results of urgent experiments in 2011 responding to the Fukushima Daiichi Nuclear Power Plant accident. Soil Sci. Plant Nutr., DOI:10.1080/00380768.2014.995584.

Kawano, M. et al. (2006) Surface reactive sites and ion adsorption modeling of schwertmannite. Nendo Kagaku, 45, 223232 [In Japanese].

Kuwahara, C. et al. (2011) Characteristics of cesium accumulation in the filamentous soil bacterium Streptomyces sp. K202. J. Environ. Radioact., 102, 138-144.

Ministry of the Environment: https://www.env.go.jp/water/dojo/ gl_ex-me/

Nuclear regulation authority: Monitoring information of environmental radioactivity level. http://radioactivity.nsr.go.jp/en/ index.html

Shaw, G. (1993) Blockade by fertilizers of caesium and strontium uptake into crops: effects on the root uptake process. Sci. Total Environ., 137, 119-133.

Tsukada, H. et al. (2002) Rice uptake and distributions of radioactive ${ }^{137} \mathrm{Cs}$, stable ${ }^{133} \mathrm{Cs}$ and $\mathrm{K}$ from soil. Environ. Pollut., 117, 403-409.

Yamashita, J. et al. (2014) Estimation of soil-to-plant transfer factors of radiocesium in 99 wild plant species grown in arable lands 1 year after the Fukushima 1 Nuclear Power Plant accident. J. Plant Res., 127, 11-22.

Zhu, Y-G. (2001) Effect of external potassium (K) supply on the uptake of ${ }^{137} \mathrm{Cs}$ by spring wheat (Triticum aestivum $\mathrm{cv}$. Tonic): a large-scale hydroponic study. J. Environ. Radioact., 55, 303-314.

Zhu, Y-G. \& Smolders, E. (2000) Plant uptake of radiocaesium: a review of mechanisms, regulation and application. J. Exp. Bot., 51, 1635-1645. 